\title{
The Chinese-Russian Slang as a Contemporary Aspect of the Russian-Chinese Language Contact
}

\author{
Olga V. Sokolovskaya* \\ Siberian Federal University \\ 79 Svobodny, Krasnoyarsk, 660041, Russia
}

Received 02.11.2015, received in revised form 22.11.2015, accepted 02.12.2015

This paper sheds some light upon the Chinese-Russian slang as a modern aspect of the RussianChinese language contact. The paper shows that there are two main types of the attitude towards the Chinese-Russian slang. The first group of people considers it to be a language game, so the attitude is mostly indifferent. The second group of the respondents has a negative attitude, which is illustrated by the author.

Keywords: Chinese, Russia, language contact, slang.

DOI: 10.17516/1997-1370-2015-8-12-2953-2959.

Research area: philology.

\section{The Chinese-Russian Language Contact in General}

If two or more languages happen to have some kind of relations, in the process of which there is a certain influence on two or more languages, such a phenomenon is called "language contact". The language contact is mainly influenced by social factors and interaction between nations. It is a complicated process that occurs between people who speak different languages and can be divided into different types according to different criteria. For instance, 1) active vs. passive contact, 2) natural vs. unnatural contact, 3) oral vs. written contact, 4) direct vs. indirect contact, 5) language contact between related vs. unrelated languages. Language contacts result in the appearance of borrowed vocabulary (loan words), mixed languages and bilingualism.
China and Russia (including the Soviet Union) have a long history of the interaction. The two countries are neighbors. The communication between the countries covers economic, military, cultural, political and other spheres of everyday life. The period of close and active interaction between China and Russia highlights the obviousness of the progress of the ChineseRussian language contact. However, the period of deteriorating relations drastically reduces the intensity of the language contact existing between China and Russia.

The trade between China and Russia contributed to the development of frequent interactions between the countries. In the process of exchanging goods people learned from each other, received knowledge about some new realia. The country, which imported this knowledge,

(C) Siberian Federal University. All rights reserved

* Corresponding author E-mail address: oliavsokol@hotmail.com 
gained information on some new goods. At the same time a new word identifying this new type of goods appeared in the recipient language. For instance, such words were "pearl" and "tea", both borrowed from the Chinese language. A massive immigration of Russian people to China began with the start of the Eastern railroad's construction at the end of the $19^{\text {th }}$ century. During the period of Chinese-Russian friendship many Chinese people went to the Soviet Union to study. Contemporarily the cultural sphere of interaction between the countries features such events as the Chinese-Russian "national years", the ChineseRussian "language years", the Chinese-Russian "years of tourism". The specificity of relationship between the countries in different periods reveals social factors influencing the Chinese-Russian language contact.

We assume that the phonetic level was free from influence in the Chinese-Russian language contact. Therefore we focus our main attention on the grammar and vocabulary, and mixed languages are in the center of our attention in the present article.

We discovered three Chinese-Russian mixed languages, they are: Kyahta mixed language, Harbin Russian pidgin and the slang of Russian students in China. Kyahta mixed language is a Chinese-Russian mixed language used by merchants on the Chinese-Russian border. In the beginning Kyahta mixed language had a structure, dictionaries, teaching materials. Both sides regarded the dictionaries and teaching materials as an example. The fall of Kyahta trade and the start of the Chinese Eastern railroad construction resulted in the spread of Kyahta mixed language. This development enriched the language. The structure of the language became weak and many variants appeared. Many dialect words entered this mixed language. There are few researchers of Kyahta mixed language. There is a lack of homogeneity in the materials of Kyahta language. At present Kyahta mixed language almost became extinct.

In the last century Harbin "Russian pingin" was spread from mouth to mouth among the citizens of Harbin. This "Russian like pidgin" only has an oral form. The written form only includes some shops signs (on displays of shops) and advertisement. The usage of the "Russian pidgin" includes: street trade, service providing, casual conversations. The type of interaction is informal. The word order in the "Russian pidgin" corresponds to the rules of the Chinese language. Speaking about the vocabulary of the "Russian pidgin", it contains words of the Russian origin, but there are words of the Chinese origin as well.

Chinese-Russian slang is a comparatively new phenomenon. We discovered that among the Russians who live in China a special language exists. This slang was found out by us in the circle of foreign students in China. This ChineseRussian slang is used by Russian people who live and study In China. The main vocabulary of this slang is Chinese, but the pronunciation and grammar rules are of the Russian language. The ordinary Russian morphology is applied.

\section{The Origin of the Chinese-Russian Slang}

The title “Chinese-Russian slang” or “现代 汉俄俚语” was given by us, as it reflects the core of such type of the language usage: it is used by a certain group of people, it has no intentional purpose to hide some information, it is created on the basis of already existing language units. The user of this slang must fulfill at least two of the following requirements, these are: usually he is a Russian person (in the vast majority of cases) and he must possess certain knowledge of the Chinese language. The usage of the slang was discovered on the mainland of China, so objectively it is a result of the Russian-Chinese language contact. 
Before becoming a pidgin a mixture of two or more languages usually passes the stage that we call "slang". But it is very unlikely that in the present geopolitical situation this ChineseRussian slang can become something more than a linguistic game, can become more well spread and be used by a large group of people. Nowadays there is no actual need in such kind of mediator between Russian and Chinese, as the number of Chinese students who study Russian language and Russian students who obtain knowledge in Chinese language increases every year.

The appearance of such slang is resulted by two main reasons. The first is the certain difficulty while translating some cultural phenomenon into another language. The word “火锅” is a vivid example. It is usually translated into Russian as "Chinese samovar", but "samovar" is a pot for drinking tea while “火锅” is a name of a dish which is cooked in a big metal pot. The slag users reject the word "samovar" for this notion and transcribe the pronunciation of this Chinese word "huo guo" saying "хуогуо". Another example is a word "мифань" which also reflects the pronunciation of the word “米饭” (cooked rice). In Russian cuisine there is no such phenomenon and a descriptive method is applied while explaining to a Russian what “米饭” is.

The second basic reason of the appearance of such slang is that any language tends to be simplified and translation into another language is an additional effort, which can be omitted when you talk to a person who knows the same languages as you are. For instance, the word “服务员” which refers to customer service personnel. It can be translated as "waitor" or "waitress" in a restaurant, "attendant" on a plane, "maid" in a hotel and etc. In order not to think how to translate it every time, the users of Chinese-Russian slang made it simple. The Chinese pronunciation of the word "fu wu yuan" becomes shorter, plus the Russian suffix and ending "-ньк-а" formed one of the most frequently used slag word "фунька".

The slang is formed on the basis of Chinese vocabulary and Russian morphology. This is the peculiarity of the slang and its main difference to Harbin Russian-Chinese pidgin and Kyahta pidgin. It's worth mentioning that the users of the slang consider it more to be a game than a real linguistic phenomenon. While living in China, Russian people use this slang during the communication with other Russians. The place of origin is not clear, but it's obvious that the centers of Russian culture on the mainland of China such as Harbin, Shanghai, Beijing, Manzhouli and some others due to a certain number of Russian citizens, Russian students have become the places where this slang appeared and is being used.

The material for the research was provided due to three main ways. The first is personal interviewing people in Harbin (China) and Krasnoyarsk (Russia). Plus during the communication with Russian people who obtain the knowledge of Chinese language the author made notes. The second way was though analyzing material from the social nets, social chats, where people are free to use any linguistic methods to express themselves. Audio material was an object of our attention too, as we took into consideration radio programs, podcasts that are made by Russians who live in China. In general 80 hours of audio material has been analyzed. The third we held an e-survey with more than 300 participants, which provided us with the information.

\section{The Vocabulary of the Chinese -Russian Slang}

The research revealed the words of the highest quantity usage. They are:

1. "Funka", the word comes from Chinese “fuwuyuan” (服务员), a working staff of restaurants, hotels, cafes and so on. There 
are several word forms, such as "fuika", "fuya", "fuwuyuanka", "fushka" and etc. Example of the word's usage: "Please ask fuika whether the dish is spicy", "Fuika has brought the food", "We should ask fuechek".

2. “Chifanit" (吃饭, means 'to eat') 与 “chifanka"(小吃部, means small café). Both words originates from the Chinese word "chifan" (吃饭) which means to eat and both of them are equality frequently used. Example of the word's usage: "We don't like to eat in the local chifanka ", "We'd better go pochifanit ('eat')", "After that we went somewhere to chifan ${ }^{1}$ ".

3. "Mafan", the word comes from Chinese "mafan" (麻烦, means some difficult, troublesome situation). There are several word forms, such as "mafanshik" (a troublesome man, a man who has many problems), "mafanshica" (a troublesome woman, a woman who has many problems).The usage of the word produced different parts of speech, such as "mafanno" (adverb), "mafanitsia" (verb) , "mafanisty" (adjective) 。Example of the word's usage: "A delegation from Krasnoyarsk is coming and I should accompany them, translate everything. It's such a mafan"; “It's mafanno to wash a car"; "You are such a mafanshik".

4. "Laowai", the word comes from Chinese “laowai" (老外, foreigner, esp. non Asian person)". There is an adjective "laowaiskyi", means something in a foreign style, something that belongs to foreigners. In China Carrefour supermarkets have a shelf with foreign goods, and the Russians call it "laowaiskaya shelf". Example of the word's usage: "A laowai can be order out of the country for the drunk driving""; "Here we are discussing topics and problems of our life in China, our foreign as we say laowaiskoi life 3 "; "We don't like laowaev here"

The lexical units above are well spread. The vocabulary of Chinese-Russian slang includes many other words, but these are with the highest frequency. The mentioned examples were provided by the slang users during the interviews, Internet survey and radio programs.

The rest of the Chinese-Russian slang vocabulary was analyzed and divided into several groups.

1) Forms of address, words that refer to certain groups of people:

"Shifu", the word comes from Chinese “shifu” (师傅, 'master hand', 'specialist', 'service person'. Russian people mostly use this word in the meaning 'taxi driver'). There are several word forms, such as "shifak", "shifer", "shifachka" ('female taxi driver'). Ex. "Shifik met me at the airport today and helped me to carry the luggage".

"Ai", the word comes from Chinese "ayi" (阿姨, 'aunt', 'nanny', 'elderly unattached woman'). The other word form is "aishka". Ex. "In our sushe ('dormitory') I always say hi to the aishki".

"Meinu", the word comes from Chinese “meinü” (美女, ‘beautiful lady'). The word form with a negative connotation is "meinuha". Ex. "Look, what a meinuha has just passed".

"Laobaisin", the word comes from Chinese “Laobaixing” (老百姓, 'common people'). The derived words include adjective "laobaisinsky" and noun "laobaisinshina". Ex. "The government rules the laobaisinom".

"Laoshi", the word comes from Chinese “Laoshi” (老师, “teacher'). Mostly used as a reference to female teachers. The derived words form with a negative connotation are "laoshara" and "laoshiha" . Ex.: "Again I don't understand what that laoshiha is saying". The derivated abstract noun is "laosharnichestvo" (means - work of teacher, teaching as an occupation). Ex.: "I have a feeling that I'm going to do laosharnichestvo for all my life".

The other Chinese-Russian slang words with the naming of people include "Laoban" 
(老板,'boss'), “futashka” (辅导, 'tutor'), “linda” (领导, 'leader', 'top-ranking personnel'), “dae” (大爷, referring to an entrance guard of a student dormitory), “sueshen” (学生, 'student'). The vocabulary above reflects the main spheres where Russian people communicate with Chinese population and their attitude towards them. It's obvious that the main sphere of interaction is the sphere of service, which includes waiters, drivers, staff of dormitories, shop assistants . At the same time there is a certain number of words from the field of study, ex. Teachers, students, tutors.

2) Study and work lexical units:

"Timbudunit", the word comes from Chinese “Ting bu dong” (听不懂, 'I don't understand'). Ex. “Today I'm timbuduniy”.

"Bumingbai", the word comes from Chinese “Bu ming bai” (不明白, 'I don't understand'). "Fuyin" the word comes from Chinese "fu yin" (复印, 'make a copy'). Ex.: "Please, otfuyin the documents".

"Jiabanit", the word comes from Chinese “Jia ban” (加班, “work overtime; work an extra shift'). Ex.: "She is not coming, laoban (boss) made her jiabanit".

"Huodong", the word comes from Chinese "Huodong” (活动, 'activity').

\section{3) Food lexical units:}

"Herfanit", the word comes from Chinese “her fan” (盒儿饭, 'food in boxes'), apart from the original word it's a verb, the meaning is "to buy food in boxes". Ex. "Again herfanit? Or may be we'd better eat at chifalovka (cafe)"

"Maidanit", the word comes from Chinese "mai dan" (买单, 'to pay the restaurant bill'). Ex.: "Pochifanil - zamaidan" (You've eaten the meal - pay the bill).

"Baofan", the word comes from Chinese “bao fang" (包房, 'private room at restaurant or karaoke'). In Russia such a thing is just appearing, while in China it's a wide spread situation when people eat at separate rooms. So the slang users didn't find the proper Russian word for what they call "baofan" or "baofanka" (add a suffix - ka).

"Mifan", the word comes from Chinese “mi fan” (米饭, '(cooked) rice'). Russian people don't eat cooked rice in the way Chinese people do. That is the main reason why this word has enriched the Chinese-Russian slang. Ex.: "Let's order two mifans".

\section{Chinese customs and habits}

The given vocabulary of the ChineseRussian slang represent the cultural words, lexical gaps which are typical for Chinese culture.

"Chabuduo", the word comes from Chinese “cha bu duo" (差不多, 'almost, nearly, just about right'). There is a certain difference in spelling of the word, ex. "chabudo", "chapuduo", "chaputuo". This lexical unit represents the notion of the Chinese culture. Ex.: "Is the weather in Beijing same as in Harbin? - Yes, chabuduo". "They choose old people and think "chabuduo"".

"Guanxi", the word comes from Chinese “guan xi” 关系, 'relationship'). There is a proverb that in China relationships are more important than money and by knowing proper people you may solve any problems. So it's an important notion of the Chinese culture. Example of the usage: "You don't take people's money, may be some guanxi".

This group of words is numerous and include such words as: "Buhaoyisi” (不好意思, feel shy; be ashamed of), "Lailaika” (“来、来”, a bus with a conductor that says "come, come") .

\section{Conclusion}

Most of the Chinese-Russian slang are formed according to the model "Chinese root + Russian siffux" or "Russian prefix + Chinese root +Russian suffix". The verbs are formed by adding Russian verbs' suffix and ending - at, it, et.Ex.: “shenbinit”(生病, fall ill), “ganbekat” (干杯, 
drink a toast; cheers), “jiabanit”（加班, work overtime), "kanit" (看,look), "kaihuet" (开会, have a meeting), "liaotiarit" (聊天,chat, talk), "maidanit" (买单, pay the restaurant bill) etc. Most nous are made by adding the suffix $-\mathrm{k}$. Ex.: “Xiaoharka”（小孩， baby），“funka”(服务员， waiter), “fatashka” (辅导,tutor), “seseka” (指说“” 谢谢、谢谢”的乞正, beggar that says “thank you, thank you")etc.

The fast majority of the Chinese-Russian slang vocabulary is made by transliteration. But there are few examples when Chinese cultural phenomenon is represented by Russian words only. Ex.: "to lose one's face" - this word group is originated from Chinese “diu mianzi” (丢面子), means to lose respect of others.
On the phrase and sentence level the slang is reflected by "A not A" word group, which is typical to the Chinese language, but not to the Russian language. For ex.: "need or don't need" (要不要), “expensive or not expensive” (贵不贵).

In general our research has shown that there are two main types of the attitude towards the Chinese-Russian slang. The first group of people considers it to be a language game, so the attitude is mostly indifferent. The second group of the respondent has a negative attitude, as it bastardizes the language. They feel that it has influenced the Russian language, so they try to avoid using it. And some people pointed out that they use the slang only on the territory of the mainland China.

\footnotetext{
Laowaicast № 1 №2009

Laowaicast № 80 №2011

Laowaicast №58 №2011

Laowaicast № 1 №2009

Laowaicast № 58 №2011

Laowaicast № 1 №2009

Laowaicast №81 №2011
}

\section{References}

Sokolovskaya, O. V., Sokolovsky, Ya. V. (2011). Factors influencing translation within the framework of language contacts: on the interaction between the Russian and Chinese languages. Journal of Siberian Federal University. Humanities \& social studies, 4(10), 1454-1461.

Perehvalskaya, E.V. Sibirski pidgin. Dalnevostochni variant. Formirovanie. Istoria. Struktira. Dissertacia na soiskanie ychenoi stepeni doctora filologicheskih nauk. St.Petersbugr, 2006.

Musorin, A.U. Leksika kyahtinskogo pidgin. Funkcionalni analis yazikovih edinic. Novosibirsk, 2004, p. 79-86.

Laowaicast. Internet source (http://laowaicast.ru/), 2009-2012. 


\section{Русско-китайский сленг \\ как современное проявление \\ русско-китайского языкового контакта}

О.В. Соколовская

Сибирский федеральный университет Россия, 660041, Красноярск, пр. Свободный, 79

Эта статья проливает некоторый свет на китайско-русский сленг как проявление современного аспекта языкового контакта между русским и китайским языками. В работе показано, что существует два основных типа отношения к китайско-русскому сленгу. Первая группа респондентов считает, что это языковая игра, так что отношение в основном индифферентное. Вторая группа респондентов имеет негативное отношение, которое представлено в статье.

Ключевые слова: китайский, Россия, языковой контакт, сленг.

Научная специиальность: 10.00 .00 - филологические науки. 